\title{
PERAN MEDIA SOSIAL DALAM TUGAS JURNALISTIK
}

\section{(Studi Kasus pada Kegiatan Jurnalis Kota Bandung)}

\author{
Reni Nuraeni, Muhammad Syahriar Sugandi \\ Program Studi S1 IImu Komunikasi Fakultas Komunikasi dan Bisnis Universitas Telkom \\ Jl. Telekomunikasi No. 1 Terusan Buah Batu Bandung \\ Email: rezn ns@yahoo.com
}

\begin{abstract}
Abstrak
Media sosial hadir sebagai perkembangan teknologi, sebagai media baru media sosial diadopsi dan dimanfaatkan dalam semua bidang, tidak terkecuali dalam tugas jurnalistik. Media sosial dijadikan jurnalis sebagai ide atau topik awal dalam pencarian berita. Penelitian ini membahas mengenai peran media sosial dalam tugas jurnalis dengan meneliti pemanfaatan media sosial dalam tugas jurnalistik dan bentuk tanggung jawab jurnalis pada pemberitaan yang bersumber dari media sosial dengan studi kasus tugas jurnalistik jurnalis media cetak dan online Kota Bandung. Menggunakan teori Gate Keeping akan dan menganalisis dari penerapan Kode Etik Jurnalistik (KEJ). Dapat disimpulkan bahwa semua jurnalis di Kota Bandung memanfaatkan media sosial sebagai data awal pencarian informasi dan untuk menguji kebenaran dan keabsahan informasi yang didapatkan dilakukan check dan recheck ke lapangan dengan melakukan wawancara dengan narasumber dan langsung terjun ke Tempat Kejadian Perkara (TKP)
\end{abstract}

Kata Kunci : Media sosial, Jurnalistik, Teori Gate keeping 


\section{Pendahuluan}

Perkembangan teknologi dan informasi saat ini ikut menentukan perkembangan hidup manusia. Seiring dengan perkembangan teknologi dan informasi, masyarakat Indonesia dihadapkan kepada era digital, dimana perkembangan informasi dikolaborasikan dengan perkembangan teknologi. Salah satu bentuk perkembangan teknologi ini adalah dengan hadirnya teknologi internet. Teknologi internet dan mobile phone semakin maju maka media sosial pun tumbuh dengan pesat.

Media sosial adalah sebuah media online dimana para penggunanya bisa dengan mudah berpartisipasi, berbagi, dan menciptakan isi meliputi blog, sosial network atau jejaring sosial, wiki, forum dan dunia virtual. Blog, jejaring sosial dan wiki mungkin merupakan bentuk media sosial yang paling umum digunakan oleh masyarakat di seluruh dunia. (http:pikiran rakyat.com)

Media sosial diawali dengan hadirnya Friendster dan Myspace, era Facebook dan Twitter, juga Google Plus, media ini membuat beberapa perubahan manusia dalam hal berinteraksi, berkomunikasi dan mendapatkan informasi. Hampir semua kalangan masyarakat dan semua profesi telah merasakan segala manfaat yang berasal dari penggunaan media sosial ini.

Tidak terkecuali, profesi jurnalis juga sangat diuntungkan dengan kehadiran media sosial, dimana dunia jurnalisme tidak bisa dipisahkan dari peranan media sosial. Mulai dari media massa konvensional seperti surat kabar, majalah, tabloid hingga media massa kontemporer seperti e-paper, dan facebook.

Jurnalisme membutuhkan media untuk menjadi wadah penyebarluasan informasi yang terdapat dalam berita. Dan dalam perkembangannya kini, media massa hadir dengan ragamnya yang semakin bervariasi. Kehadiran internet semakin menguatkan pendapat bahwa media (dalam hal ini media on-line) dapat memberikan manfaat yang besar dalam kehidupan manusia, termasuk dunia jurnalisme. 
Selain sebagai sarana penyebar luas informasi, media sosial ini juga dimanfaatkan jurnalis sebagai referensi atau sumber berita. Penggunaan sosial media sebagai sumber pemberitaan dapat terlihat dari hasil survei yang dilakukan salah satu lembaga di negara Amerika Serikat terhadap 500 wartawan yang berasal dari 15 negara, dan hasilnya sebanyak 47 persen di antaranya menggunakan Twitter sebagai sumber berita dan 30 persen lainnya menggunakan Facebook.

Penggunaan media sosial sebagai sumber informasi ini kita coba hubungkan dengan kasus yang saat ini dengan hangat diperbincangkan masyarakat luas yaitu salah satu kader Partai terbesar di Indonesia sehubungan dengan kasus korupsi dan sedang buron Nazarudin. Saat ini ramai dibicarakan Nazarudin vs media sosial, dimana nyanyian Nazarudin bergema di setiap media.

Stasiun Metro TV selalu menayangkan hasil wawancara dengan Nazarudin bahkan memberikan slogan khusus mengenai pemberitaan Nazarudin dengan title "nyanyian Nazarudin", begitu juga Iwan Piliang (Presstalk) juga mengaku melakukan wawancara langsung via Skype dengan Nazzaruddin.

Bagi penonton atau pendengar berita yang berkaitan dengan adanya tayangan atau berita yang menyatakan telah melakukan wawancara Nazarudin yang dilakukan wartawan melalui media sosial adalah bukti baru dalam perjalanan kasus yang membelit partai terbesar di Indonesia ini, tetapi tidak bagi partai yang terkait yang menganggap hasil wawancara adalah rekayasa yang tidak bisa diukur kebenaranya.

Ketua Dewan Pembina Partai Demokrat melanjutkan lagi tudingannya,bahwa terdapat suatu indikasi pihak-pihak luar yang menginginkan Partai Demokrat tersebut hancur.Para politisi partai yang berkuasa itu sengaja di hadapkan satu dengan lainnya oleh media massa, sehingga mempertajam konflik diantara mereka sendiri yang disaksikan oleh jutaan pemirsa dari seantero Indonesia.( http://politik.kompasiana.com) 
Selain tudingan terhadap media sebagai alat mempertajam konflik juga dapat terlihat di situs partai Demokrat yang menuliskan berita dengan judul "Iwan Piliang, Pahlawan atau Orang Bayaran?". Perdebatan mengenai aktor mana yang salah ataupun yang benar, yang pasti kasus ini menarik dimana keberadaan media sosial yang digunakan dalam tugas jurnalistik dipertanyakan keabsahannya.

Point penting yang harus dimiliki jurnalisme diantaranya adalah Kewajiban pertama jurnalisme adalah soal kebenaran, loyalitas kepada warganegara, esensinya ketat terhadap verifikasi, dII (Kovich, $2001: 12$ )

Menyangkut masalah kasus Nazarudin ini, media sosial semacam twitter, facebook, skype, blog dan youtube dapat digunakan sebagai sumber berita asalkan tetap dilakukan verifikasi terhadap narasumbernya. Tugas jurnalistik yang dibatasi dengan waktu deadline menjadikan tugas pencarian informasi menjadi hal penting yang menjadi perhatian jurnalis, karena jika informasi yang didapatkan dari media sosial tanpa dicari kebenarannya kebenarannya karena alasan deadline

Mengupas soal kebenaran sumber berita merupakan hal yang menarik untuk diteliti, karena jikasalah menggunakan sumber informasi dapat berakibat fatal bagi tugas jurnalistik dan memberikan berita yang bohong merupakan pelanggaran Kode Etik Jurnalistik (KEJ), oleh karena itu penelitian ini membahas mengenai bagaimana penggunaan media sosial dalam tugas jurnalis dengan mengangkat studi kasus tugas jurnalistik para jurnalis di Kota Bandung. 


\section{Kajian Pustaka}

\section{Wartawan dan Sumber informasi}

Jurnalistik secara harfiah artinya kewartawanan atau kepedulian. Kata dasarnya junal (journal) artinya laporan atau catatan, Maka jurnalistik dapat diartikan sebagai proses "aktivitas" atau "kegiatan" mencari, mengumpulkan, menyusun, mengolah / menulis, mengedit, menyajikan, dan menyebarluaskan berita kepada khalayak melalui saluran media massa (Suryawati, 2011:4).

"Wartawan atau reporter adalah seseorang yang bertugas mencari, mengumpulkan dan mengolah informasi menjadi berita, untuk disiarkan melalui media".(Djuroto, 2002 : 22). Banyak anggapan bahwa wartawan itu pers padahal wartawan adalah sebagian dari manajemen pers, wartawan adalah sebagai sub sistem dari sebuah sistem pers.

Undang-Undang No.40/1999 tentang Pers, Bab I, ayat 4 : Wartawan adalah orang secara teratur melaksanakan kegiatan jurnalistik. Dengan demikian, siapa pun yang melakukan pekerjaan yang berkaitan dengan warta atau berita, bisa disebut wartawan, baik mereka yang bekerja pada surat kabar, majalah, radio, televisi, film maupun kantor berita.

Wartawan akan tertarik dengan peristiwa yang mengandung nilai berita. Wartawan yang mahir dalam mencari berita dan menulis berita bisa menbedakan mana berita yang bernilai dan mana berita yang bersifat iklan atau promosi. Bagi seorang wartawan, bahan berita adalah cerita yang menarik perhatian pembaca, skandal atau masalah sosial yang menarik perhatian pembaca sehingga masyarakat luas merasa sangat berkepentingan dengan berita yang dibuat oleh wartawan.

Kualitas berita yang dibuat wartawan akan menentukan kredibilitas lembaga media massa dan kredibilitas wartawan itu sendiri. Menurut Totok Djuroto dalam bukunya Manajemen Penerbitan Pers, untuk bisa mendapatkan berita yang dapat dipercaya dilukakan dengan cara :

1. Wartawan mendapatkan beriata atau informasi langsung dari informan (sumber berita), misalnya menerima press release dari intansi pemerintah atau swasta. Istilah 
menerima di sini sifatnya pasif. Artinya, bahan berita yang diterima sudah matang, tinggal mengedit dan memuatnya saja.

2. Melakukan pencarian berita dengan melakukan peliputan acara adalah, penulis menghadiri undangan suatu kegiatan yang sudah dijadwalkan sebelelumnya. Misalnya, menghadiri upacara pelantikan pejabat baru di lingkungan pemerintahan. Peluncuran buku baru dari suatu perusahaan atau acara jumpa pers. Dalam menghadiri acara ini, penulis mencatat peristiwa atau kejadian yang sudah dipersiapkan terlebih dahulu oleh informannya. Misalnya, penulis berita mendapat undangan peresmian suatu pabrik. Acara peresmian itu sendiri sudah padat dengan data, penulis tinggal mencatat, memilih dan mengolahnya menjadi berita. Cara ini lebih aktif dibanding dengan yang pertama.

3. Menggali berita. Dalam hal ini wartawan melakukan kegiatan pencarian data dan informasi sendiri terhadap suatu kejadian atau peristiwa. Data yang ada diperoleh dengan menggali informasi dari berbagai pihak Informasi atau data tersebut ialah menjadi berita. Inilah yang disebut dengan penyelidikan untuk berita (investigated news).(Djuroto, 2002: 53)

\section{Interaksi Wartawan dengan Kode Etik Jurnalistik}

Wartawan memiliki hak untuk membuat sebuah berita yang bernilai, namun wartawan juga harus memiliki moral dan tanggung jawab sosial sehingga tidak menjerumuskan pihak lain. Aspek moral berhubungan dengan hati nurani. Apakah ia akan menurunkan sebuah berita yang hanya mengandalkan "news value" atau mengedepankan tanggung jawab moral pribadinya. Inilah filter pribadi dari kebebasan pers. Effendy mengungkapkan :

Seorang wartawan harus memiliki hati jurnalistik (journalistic consience) ketika hendak mempertanyakan sebuah berita dengan ukuran dirinya atau keluarganya sendiri yang terlihat dalam berita tersebut. Bagaimana kalau tersangka itu adalah anak kita? Ini 
sebuah contoh. Dengan demikian, berita yang ditulis benar-benar sebuah berita yang sudah dipikirkan dalam berbagai aspek dengan cara bijaksana. (Sobur, $2001: 120$ ).

Mencari berita merupakan tugas wartawan. Kegiatan ini pada dasarnya dapat dilakukan dilaksanakan wartawan sesuai dengan waktu yang dapat disesuaikan dengan jadwal wartawan masing-masing. Dalam kegiatan penggalian informasi, wartawan harus tetap bekerja secara objektif, balance dan akurat, rumusnya $5 \mathrm{~W}$ dan $1 \mathrm{H}$. Seorang wartawan dalam meliput dan menulis berita tidak boleh memihak, tapi harus berlaku adil dan memberi kesempatan yang sama dalam pemberitaan kepada semua sumber berita. Cara pemberitaan yang dibuat wartawan dan sumber berita yang akan dijadikan relasi kerja sudah diatur dalam kode etik jurnalisitik pada Bab II (pasal 5 s/d pasal 9) dan Bab III (pasal $10 \mathrm{~s} / \mathrm{d}$ pasal 15).

Ada beberapa persyaratan agar kode etik itu bisa berfungsi (Bertens, $2000: 282$ ) :

1. Kode etik itu dibuat oleh profesi itu sendiri. Kode etik tidak akan efektif bila merupakan hasil dari pemerintah atau dari organisasi lain karena tidak ada aspek penjiwaan dari profesi itu sendiri.

2. Kode etik harus merupakan pengaturan diri (self regulation) dari profesi itu sendiri. Dengan membuat kode etik maka akan menetapkan hitam atas putih niatnya mewujudkan nilai-nilai moral yang dianggap hakiki.

3. Pelaksanaannya harus diawasi terus-menerus. Kode etik akan mengandung sanksisanksi yang dikenakan bagi pelanggar. Kasus-kasus ini akan dinilai dan ditindak oleh suatu dewan kehormatan atau komisi yang dibentuk khusus untuk itu. 


\section{Teori Gatekeeping}

Teori ini dipergunakan dengan pertimbangan banyaknya sumber informasi yang jurnalis dapatkan di media sosial tapi tidak begitu saja diadopsi tetapi terjadi proses memilih dan memilah informasi yang sesuai dengan medianya dan juga terjadi proses pengecekan informasi yang didapatkan sehingga layak untuk disiarkan sebagai hasil akhir tugas jurnalistik.

Proses gatekeeping merupakan proses yang dilihat dari $\mathbf{X} \mathbf{1}, \mathbf{X} \mathbf{2}, \mathbf{X} \mathbf{3}$, dan $\mathbf{X} \mathbf{4}$ berupa berita, artikel atau informasi. Berikut Wesley dan Malcolm menggambarkan konsep Gatekeeper dalam Proses komunikasi massa :

\section{Gambar 3. 1}

\section{Proses gatekeeping (Westley and MacLean's Model of Communication)}

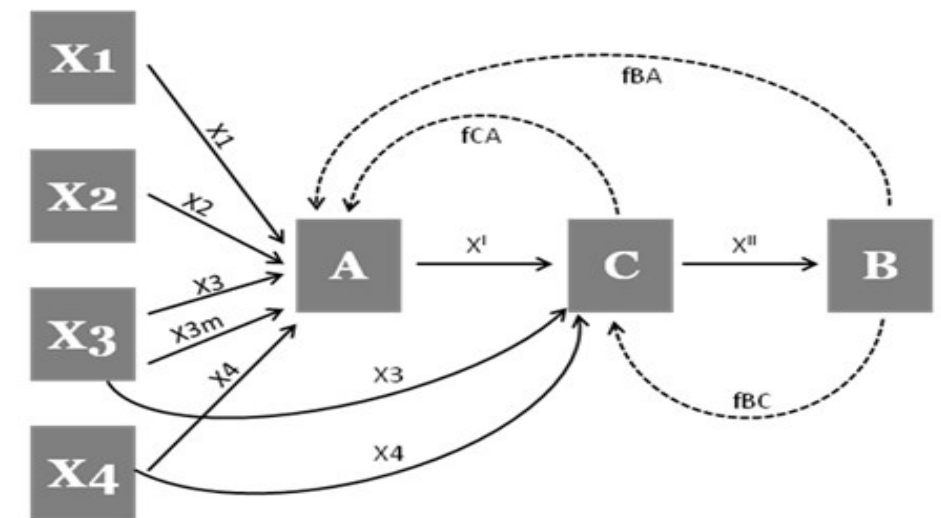

$\mathbf{X n}$

Sumber: (Ardianto, 2009:31-38) 
Berdasarkan penjelasan diatas Teori dan Proses Gatekeeping sebuah pengumpulan informasi dan menyerahkannya bersamaan ke (C), yang juga dapat mengumpulkan informasi secara langsung, yang kemudian akan diteruskan ke (B). Ruang untuk rantai umpan balik yang lebih mengarah kembali rantai komunikasi dari (B) ke (C) dan dari (B) ke (A), dan dari (C) ke (A). 


\section{Pembahasan}

\section{Pemanfaatan Media Sosial dalam Tugas Jurnalistik}

Jurnalistik berarti kewartawanan atau kepedulian. Kata dasarnya jurnal (journal) artinya laporan atau catatan, Maka jurnalistik dapat diartikan jurnalistik kegiatan mencari, mengumpulkan dan menyebarluaskan berita kepada khalayak melalui saluran media massa (Suryawati, 2011:4).

Informasi dan data merupakan bahan pokok jurnalis dalam membuat berita yang nantinya akan dikonsumsi pembaca/pemirsa. Sumber informasi bisa jurnalis dapatkan dari sumber yang dianggap mempunyai kredibilitas dalam memberikan informasi yang diperlukan.

Sumber berita harus layak dipercaya dan menyebutkan nama sumber, artinya sumber-sumber yang tidak disebutkan identitasnya merupakan isu yang tidak bisa dipertanggung jawabkan. Oleh karena itu dalam memilih narasumber hsebagai sumber informasi harus diperhatikan keahlian dan kredibilitasnya karena ucapan atau data yang diberikan akan dijadikan informasi yang akan dibagikan kepada masyarakat dalam bentuk berita. Berikut adalah penjelasan mengenai sumber berita yang didapat dilihat dari ;

a. Sumber Berita berdasarkan Sifatnya, artinya sumber yang bersifat formal dan informal. Formal merupakan sumber berita yang resmi misalnya wartawan meliput kegiatan ke pemerintahan seperti peliputan seputar kegiatan gubernur atau bupati wali kota dan lain". sedangkan informal merupakan sumber berita yang tidak resmi, misalnya berita yang diperoleh dari anggota masyarakat atau tokoh masyarakat, ilmuan atau peneliti lapangan. Seperti berita kejadian yang berlangsung disuatu tempat perampokan, kecelakaan dan lain-lain.

b. Sumber Berita berdasarkan Materi isinya, Menurut Errol Jonathan (dalam Sumadiria, 2008:98), berdasarkan materi isinya, sumber berita dapat diklasifikasikan kedalam tiga kelompok besar yaitu Paper trail maksudnya bahan yang tertulis atau tercetak seperti makalah atau dokumen. Electronic trail maksudnya sumber dari perangkat elektronik 
semacam internet untuk menggali sumber informasi. dan People trail maksudnya orang sebagai narasumber untuk menggali dalam klasifikasi nara sumber.

c. Kedudukan dan Kredibilitas Sumber berita, bagi seorang wartawan, keahlian dan kredibilitas sumber berita merupakan prioritas dan sangat penting, karena dalam hal ini wartawan tidak hanya mendapatkan berita, tetapi harus dapat mengembangkan sikap kritis karena tidak setiap sumber berita dan bahan berita dapat dijadikan berita.

Electronic trail maksudnya sumber dari perangkat elektronik semacam internet untuk menggali sumber informasi atau yang saat ini dikenal dengan istilah media sosial merupakan alternatif sebagai media yang digunakan untuk memenuhi dan mendapatkan informasi dan komunikasi. Jurnalis adalah penyebar informasi yang akan disebarkan kepada masyarakat. Dalam kegiatan jurnalistik, seorang jurnalis bisa mendapatkan berbagai keuntungan dari adanya media sosial. Media sosial Media sosial merupakan medium awal memperoleh informasi langsung dari lapangan yang makin diperhatikan jurnalis.

Media sosial bisa merupakan sarana yang dapat dikatakan efektif yang dapat dikatakan paling cepat dalam mendapatkan data, dengan adanya media sosial jurnalis bisa mendapatkan sumber berita yang dianggap kompeten tanpa harus terjun ke lapangan langsung dalam pencarian ide berita. Melalui media sosial, wartawan mudah mendapatkan ide peliputan dan fenomena yang sedang ramai dan dibutuhkan masyarakat.

Informasi mengenai berita yang telah terbit/disiarkan ataupun yang akan diangkat sebagai topik berita biasanya bisa didapatkan jurnalis dari berbagai sumber termasuk dari media online.

Keuntungan atau manfaat media sosial yang dapat dijadikan sumber informasi awal atau ide pencarian berita. Manfaat media sosial untuk mengetahui isu yang sedang hangat diperbincangkan masyarakat yang bisa diperdalam di pemberitaan. Wartawan sebagai 
profesi yang sangat membutuhkan media sosial harus menguasai teknologi karena dengan penguasaan teknologi ini dapat mempermudah setiap pekerjaan yang dilakukan wartawan.

Pemanfaatan media sosial sebagai sumber informasi dalam tugas jurnalistik dikarenakan keuntungan yang jurnalis dapatkan dari perkembangan teknologi yang satu ini. Media sosial mempunyai kecepatan informasi media sosial sering melampaui kecepatan info liputan dari kantor, selain itu juga media sosial dijadikan sarana informasi yang kemudian saya kembangkan isunya di lapangan

Tanggung Jawab Jurnalis dalam Hal Pemberitaan yang Bersumber pada Media Sosial

Tanggung jawab jurnalis dalam tugas jurnalistik harus diawali ketika memulai proses mencari, mengumpulkan, mengolah sampai menyiarkan berita. Dalam menjalankan tugas jurnalistik, jurnalis harus berpatokan kepada kode etik yang berlaku.

Kode etik bagi jurnalis adalah panduan atau aturan yang dipergunakan dalam melakukan tugas jurnalistiknya. Kode etik yang dipakai saat ini adalah kode etik jurnalistik yang dirumuskan pada tanggal 14 Maret 2006 bertempat di Jakarta dirumuskan Kode Etik Jurnalistik yang dihadiri 29 dari 35 organisasi pers yang diundang, terdiri dari 27 organisasi wartawan dan 2 organisasi perusahaan pers. Pada hal ini menyepakati rumusan mengenai Penguatan Peran Dewan Pers dan Standar Organisasi Wartawan yang terdiri dari 11 pasal, lebih banyak 4 pasal dari kode etik sebelumnya menampung lebih lengkap persoalanpersoalan yang berkembang dalam media cetak dan elektronik.

Pemanfaatan media sosial yang digunakan sebagai ide awal pemberitaan tetapi pada hakekatnya hanya sebatas ide atau informasi awal karena jurnalis harus tetap melakukan proses peliputan. 
Kewajiban mencari kebenaran mengenai informasi yang didapatkan dari media sosial dengan menjunjung kebenaran dan keabsahan informasi sebelum disampaikan kepada pendengar ataupun penonton. Jadi ketika jurnalis mendapatkan sumber informasi yang berasal dari media sosial jangan langsung dijadikan berita tetapi harus dilakuan check ricek mengenai keabsahan informasinya. Media sosial yang diasosiasikan dengan online, internet, dan segala pengembangannya, Facebook,Twitter, Blackberry Mesengger (BBM), adalah bentuk baru ekspresi dari yang kemudian dijadikan narasumber. Kemajuan teknologi komunikasi memungkinkan itu. Bahwa wartawan dituntut mengetahui bobot atau isi atau mengutip bagian mana atau tentang siapa dari media sosial, itu sudah dengan sendirinya.

Keabsahan informasi bisa jurnalis dapatkan dengan cara melakukan chek dan recheck kebenaran informasi dengan cara terjun langsung ke tempat kejadian perkara, ataupun menghubungi narasumber langsung dengan melakukan wawancara mengenai isu dan topik pemberitaan yang sedang hangat dibicarakan mâsyarakat.

Mengadakan wawancara pada dasarnya merupakan upaya menggali keterangan dari orang lain. Dalam jurnalistik wawancara selalu dimaksudkan sebagai usaha untuk mendapatklan berita, komentar atau pendapat berkaitan dengan sesuatu yang menyangkut otoritas yang dimiliki orang tersebut

Kode Etik Jurnalistik yang dipergunakan jurnalis dalam melakukan tugas jurnalistik khususnya mengenai sumber pemberitaan yang didapatkan dari media sosial adalah dengan menerapkan Pasal $\mathbf{3}$ Kode Etik Jurnalistik yang berbunyi "Wartawan Indonesia selalu menguji informasi, memberitakan secara berimbang, tidak mencampurkan fakta dan opini yang menghakimi, serta menerapkan asas praduga tak bersalah". Dengan penafsiran "Menguji informasi berarti melakukan check and recheck tentang kebenaran informasi itu". 


\section{Simpulan}

1. Tugas jurnalistik membutuhkan informasi dan data sebagai bahan pokok penulisan berita, maka sumber informasi dalam tugas jurnalistik mejadi langkah awal dalam pencarian berita. Hadirnya media sosial menjadikan tugas jurnalistik jurnalis menjadi sedikit ringan karena dengan melakukan pencarian informasi dan ide liputan akan semakin cepat, Kecepatan informasi media sosial sering melampaui $\begin{array}{llll}\text { kecepatan } & \text { dinfo kantor }\end{array}$ (redaktur/asred/korlip/sesamawartawan)/wartawan media lain/narasumber(humas) dan juga ketika jurnalis kehilangan ide atau sumber liputan, media sosial dapat dijadikan alternatif yang sangat membantu tugas jurnalistik.

2. Sumber berita menjadi hal yang penting dalam tugas jurnalistik, maka jurnalis harus berhati-hati memilih orang sebagai sumber berita informasi yang akan dikutip atau sebagai bahan penulisan. Cari informasi dari beberapa sumber sehingga keakuratannya dapat dicapai.Bentuk tanggung jawab jurnalis atas pemberitaan yang bersumber dari media sosial adalah dengan kegiatan chek dan recheck dan dalam pelaksanaan tugas jurnalistik harus berpedoman kepada Kode Etik Jurnalistik (KEJ). Kode Etik Jurnalistik yang dipergunakan jurnalis dalam melakukan tugas jurnalistik khususnya mengenai sumber pemberitaan yang didapatkan dari media sosial adalah dengan menerapkan Pasal 3 Kode Etik Jurnalistik yang berbunyi "Wartawan Indonesia selalu menguji informasi, memberitakan secara berimbang, tidak mencampurkan fakta dan opini yang menghakimi, serta menerapkan asas praduga tak bersalah". Dengan penafsiran "Menguji informasi berarti melakukan check and recheck tentang kebenaran informasi itu". 


\section{Daftar Pustaka}

Djuroto, Totok Djuroto. 2010. Manajemen Penerbitan Pers. Yogyakarta: Rake Sarasin. Kovach, Bill \& Tom Rosentiel. 2001. The Element of Journalism. USA: Three River Perss.

Milles, Martthew \& Huberman, A. Michael. 1992. Analisis Data Kualitatif. terjemahan, Rohidi, Tjetjep Rohendi. Jakarta: UI Press.

Sobur, Alex. 2001. Etika Pers Profesionalisme dengan Nurani. Bandung: Humaniora Utama Press

Sugiyono (2009). Metode Penelitian Kuantitatif Kualitatif dan R\&D (Edisi ke 8). Bandung: Alfabeta.

Sumber lainnya :

www.demokrat.or.id/2011

http://politik.kompasiana.com

http://www.pikiran-rakyat.com

Kode Etik Jurnalistik 
JURNAL LISKI | Vol. 3. No. 1 | 2017

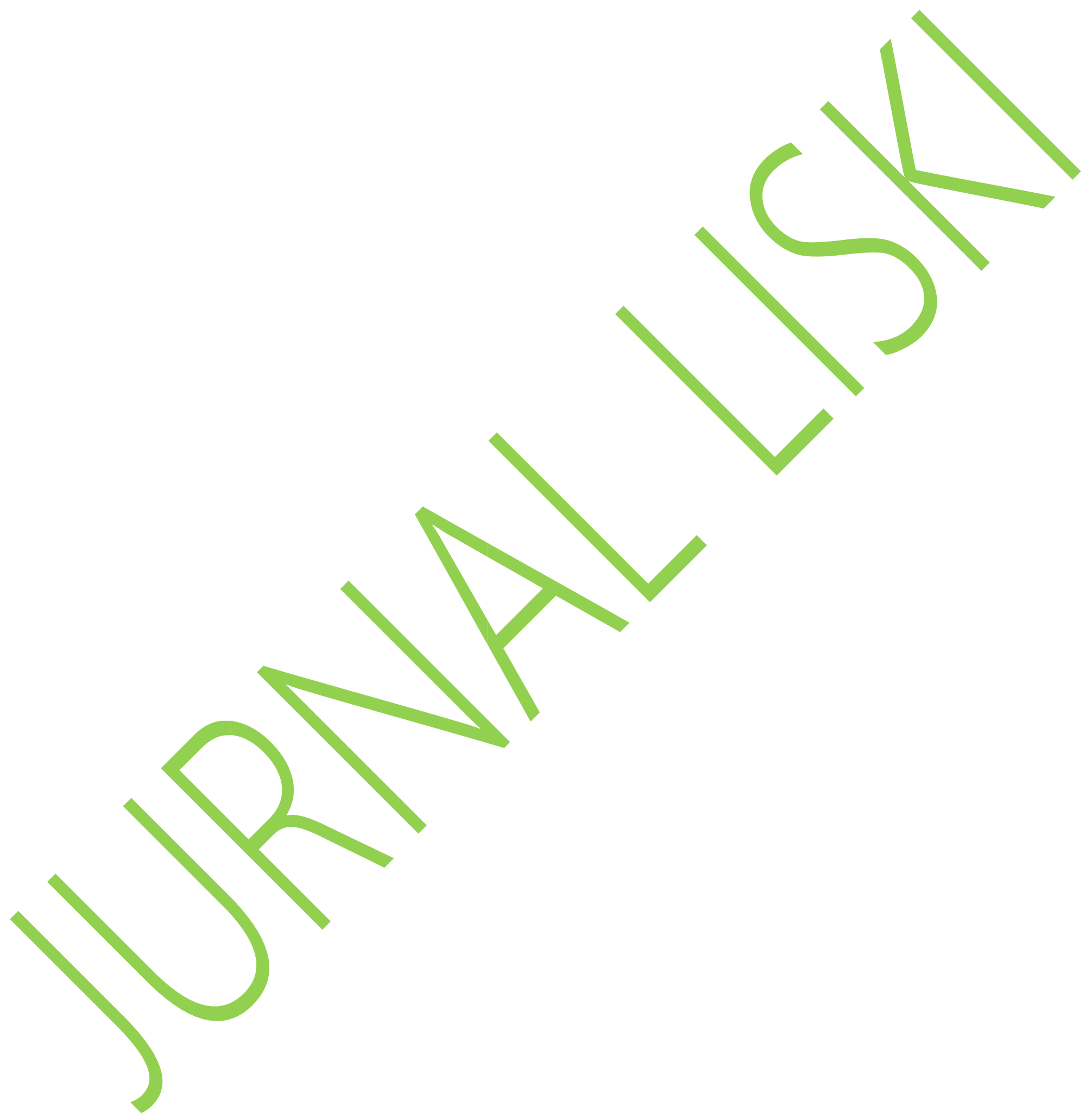

